\title{
London-Bahrain Archaeological Expedition: 1994 and 1995 excavations at Saar, Bahrain
}

\author{
ROBERT KILLICK ${ }^{1}$, SARA BLAKENEY ${ }^{2}$, SHAHINA FARID ${ }^{3}$, ALISON HICKS ${ }^{4}$, \\ MARTIN HICKS ${ }^{4}$, JENNIFER KIELY ${ }^{5}$ AND ALEX WASSE ${ }^{1}$ \\ ${ }^{1}$ Institute of Archaeology, University of London, ${ }^{2}$ Faculty of Anthropology \& Archaeology, \\ University of Cambridge, ${ }^{3}$ Pre-Construct Archaeology, London, ${ }^{4}$ Canterbury Archaeological \\ Trust, England and ${ }^{5}$ Faculty of Anthropology, University of Michigan, Ann Arbor, USA.
}

The long-term aim of the project is to excavate the entire central area of the Dilmun settlement. During the 1994 and 1995 seasons a further twelve buildings were excavated, most of them located along the main arteries of the settlement. A resistivity survey, followed by selective excavation, determined the size and extent of the site. A well excavated on the eastern flank provided valuable information about the level of Bahrain's aquifers in the Early Dilmun period.

Excavations at Saar took place over ten weeks in 1994 and twelve weeks in 1995 (1). Work was concentrated along both sides of Temple Road, in the block of houses northwest of the temple, in House 206 on South Alley and Houses 53, 54 and 60 along Main Street (2). Results will be described clockwise starting from the northwest corner of the settlement (Fig. 1).

\section{Northwest housing block: houses 205,} 208, 209 (Martin Hicks)

Immediately northwest of the temple, along Main Street, is a block of five adjoining houses. Houses 202-204 and part of House 205 have been reported on previously (3). Here we comment further on House 205 and on Houses 208 and 209 (Fig. 2 ). These three houses continue the pattern of presenting a blank façade on the western side of Main Street. Access to all houses in this block was originally off one of the small open squares (Area 239) which are beginning to emerge as a feature of the Saar settlement. Houses 208 and 209 could also be entered from the northwest, indeed these may have been the main entrances. The blank street façade clearly has some significance: it is characteristic of all those houses on both sides of Main Street north of the temple, whereas those to the south do have doorways out into Main Street.

The schematic house plans belie the complexity of development within each house. As in many of the Saar houses, lengthy floor sequences, blocked doorways, changes in room use, expansion and contraction can all be detected in the archaeological record. 


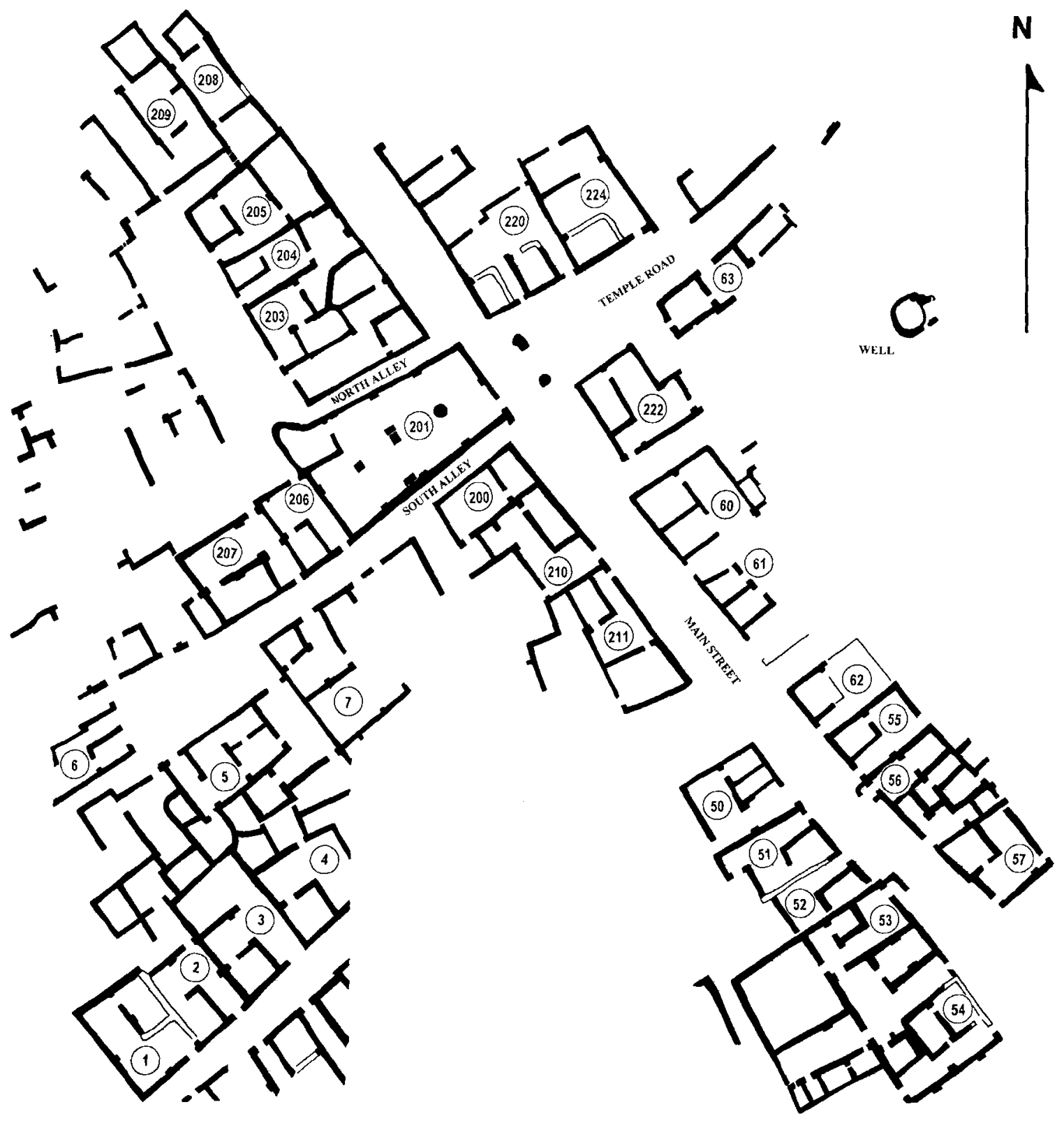

Fig. 1.

Schematic plan of the central part of the town (as at end of 1995 season). 


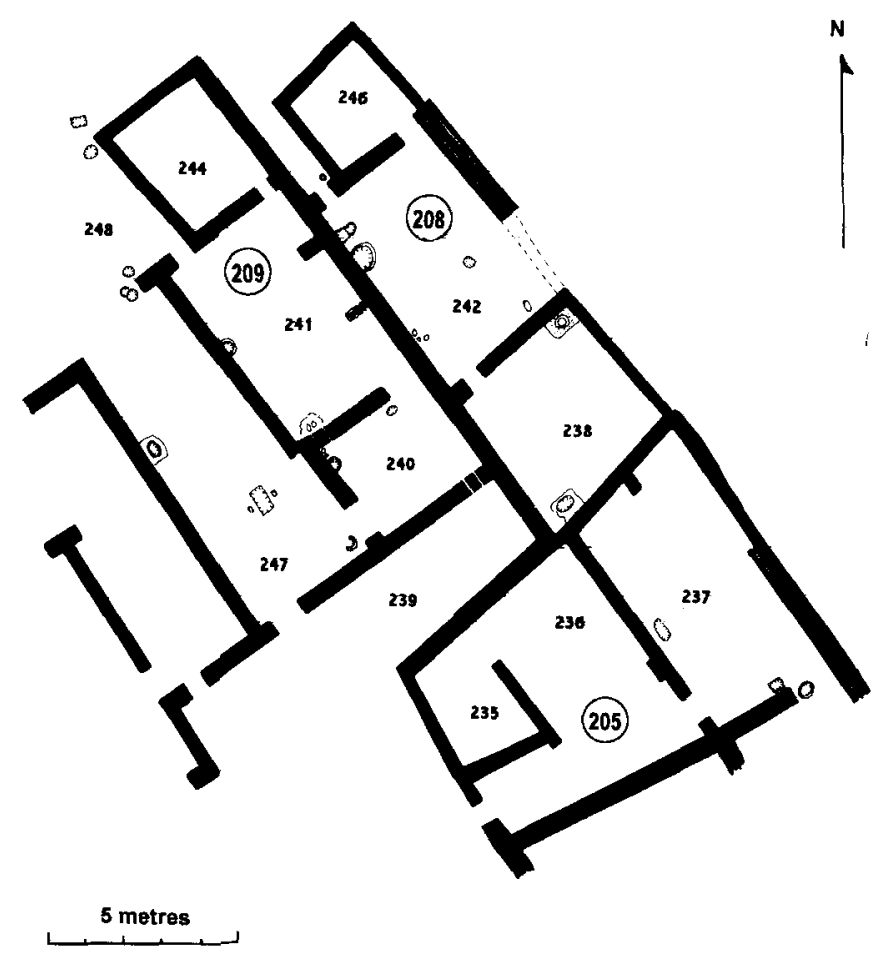

Fig. 2.

Schematic plan of Houses 205, 208, 209.

\section{HOUSE 205}

House 205 represents a standard threeroomed Saar house: L-shaped yard, inner rectangular room, second courtyard at rear. Other examples can easily be identified on the general plan (Houses 211 and 224, for example). Areas 235 and 236 have been described previously. Subsequent excavation through the latest series of floors in the rear yard (Area 237) suggests that the house was originally two-roomed. On the northwest wall of the room, the stub of an earlier back wall was found $2.6 \mathrm{~m}$ west of the later line, corresponding to a break in the main southeast wall of the house.

This suggests that Main Street was wider in this earlier phase, a hypothesis confirmed in 1995 when excavations in Main Street against the wall of House 202 revealed sand underlying the wall. This was in contrast to excavations against the wall of House 220 on the opposite side of Main Street, which revealed a sequence of superimposed house walls on the same line.

In this instance, then, we can see a development from a two-roomed to a threeroomed house, but this is not a general chronological indicator at the site, as we have both three-roomed houses that are relatively early in our sequence (such as House 224) and two-roomed houses that are relatively late (Houses 100, 104).

\section{HOUSE 208}

House 208 represents a variation on the three-room plan. An external passage in the northwest corner led through a doorway into Area 242. Along the southwest wall of this area lay the domestic fittings: a rectangular low platform with an associated small pit and, further along, a circular, plaster-lined hearth. This 
same wall was standing sufficiently high for a small niche to have been preserved. From Area 242, there were doorways to the smaller room 246 to the north and into a second yard to the south (Area 238). Room 246 was devoid of domestic installations. Originally, there had been a doorway from Area 238 providing access to a small alley and then to an open square. The small alley, however, appears to have acted as a sand trap. Sand accumulated against doorways to both House 208 and 209. In the case of the door into Area 238, there is clear evidence that so much sand accumulated against the door that it could not be opened and it fell into disuse. The door itself was subsequently removed and the entrance blocked up, as was the nearby entrance into House 209.

\section{HOUSE 209}

The plan of House 209 is a divergence from our standard house plans at Saar. An entrance from the northwest end provided access to the middle room of a range of three (Areas 240, 241 and 244). A long courtyard occupied the western flank of the house (Area 247) providing access at the southeast end out into an open public space (Area 239). A glance at the plan might suggest that the enclosure of this area was a secondary feature and that originally Area 247 was an open passage between the square 239 and Area 248 to the northwest. However, selected excavations against wall abutments and in corners showed that all the walls of this house were contemporary and that from the time of its construction Area 247 was an integral part of the building. At the southeast end, Area 247 had a doorway which provided external access, so the yard must have been an enclosed area, but there is no stone wall at the northwest end, and at least one associated surface spills out over much of Area 248. There must have been a flimsier

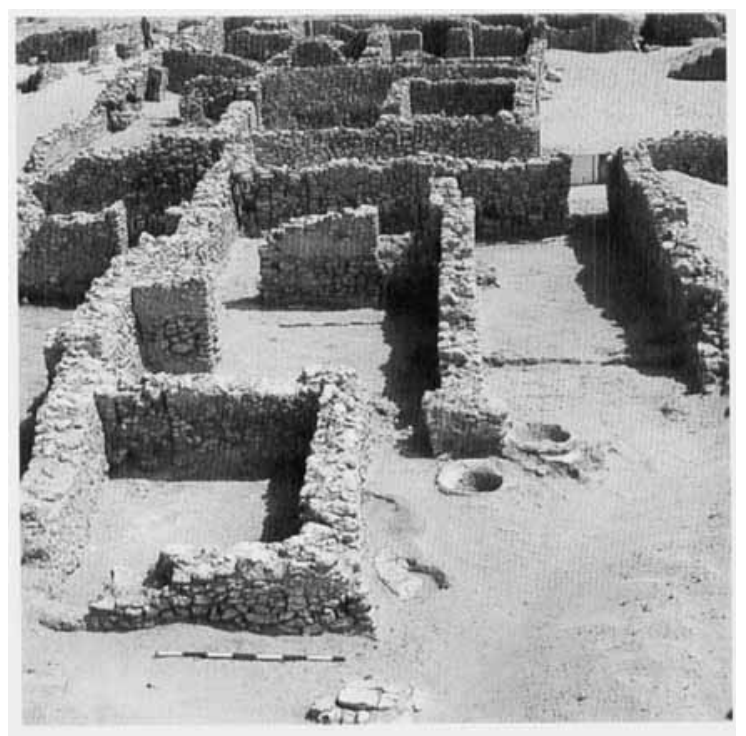

Fig. 3.

House 209 seen from the NW.

construction at this end, enclosing and sealing off Area 247 and part of 248. Whatever it was (perhaps a barasti screen) it must have been substantial enough to protect this side of the house from the prevailing northwest wind, otherwise sand would simply have blown in and covered Area 247 in no time at all.

In Area 248 was a total of five plastered basins, a group of three circular ones next to the northeast end of Area 247 and two close to the outside corner of Area 244 (Fig. $3)$. Four of these were circular, with diameters ranging from $55-70 \mathrm{~cm}$, and the fifth was a rectangular basin $40 \mathrm{~cm}$ deep. Near the north entrance to Area 247 was a basin with a stone surround, and in the middle of the room a rectangular hearth with a single square post hole either side, perhaps where a wooden spit had been constructed, or a frame to hang a pot above the fire. In the southeast corner, partly blocking the entrance to Area 240, was a plaster-lipped hearth.

Although there was a concentration of domestic debris in Area 247, ovens and ba- 


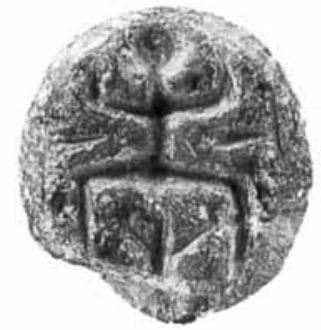

Fig. 4.

Seal. 4139.01. House 208, Area 242. Persian Gulf style. Mottled green stone, perhaps serpentine. Design: schematic human figure with arms raised and legs apart with knees bent to form three sides of a rectangle, mirroring position of the arms. Plant motif between the legs, unidentified fringed motif on either side of figure at waist level. Diameter $1.64 \mathrm{~cm}$; height $1.14 \mathrm{~cm}$.

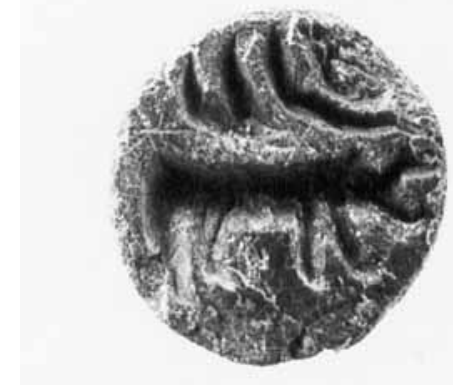

Fig. 5.

Seal. 4197.03. House 209, Area 247. Persian Gulf style. Pale grey stone with face darker, possibly burnt. Reverse has a single incised line at right angles to the perforation. Design: a stylised horned quadruped, facing right.

sins were also found in Areas 240 and 241, making it difficult to see much functional variation between these rooms. Area 244, on the other hand, was devoid of any installations. A curious feature of this room was that its only doorway was blocked up during the lifetime of the house. There is no apparent reason for this, and the condition of the floors and walls inside the room give no indication that the room had fallen into disrepair and had been sealed up for this reason.
The north side of temple road: houses 220-224 (Alison Hicks \& Sara Blakeney) HOUSE 220

In its earliest phase House 220 was two separate houses, each consisting of the basic two-room unit. Subsequently, however, the party wall between the two houses was partly demolished, turning the two houses into a single residence, a pattern that has also been noted elsewhere, in House 53 for example. Both houses had doorways leading off the north side of Temple Road, and rear entrances leading into an area for which we have as yet been unable to establish the limits (Fig. 6).

When the house was converted into a single residence, both doorways onto Temple Road continued in use. However, inside the western doorway was a typical range of domestic installations, in this case a fragmentary plastered basin to the left and a plastered feature and hearth on the right, while the eastern entrance-way was devoid of any features.

Opposite the entrance to the inner room, Area 311, eighty-six stake holes were found, in five distinct groups (Fig. 7). One group against the east wall of the house appeared to be linear, but otherwise the pattern appeared random. Others lay in front of the doorway into the smaller room. It is difficult to find a single convincing explanation for their presence and distribution across this part of the floor. All the groups did not necessarily serve the same function and some, of course, may represent a repeated event - one pole, for example, being thrust into the floor in a slightly different place at the end of the day's work.

In the same phase, a room (Area 315) and yard (Areas 313/314) were also added to the back of the house, although it is not yet clear how these areas relate functionally to House 220. The character and nature of the surfaces in Areas 313 and 314 were markedly different, which suggests that there 


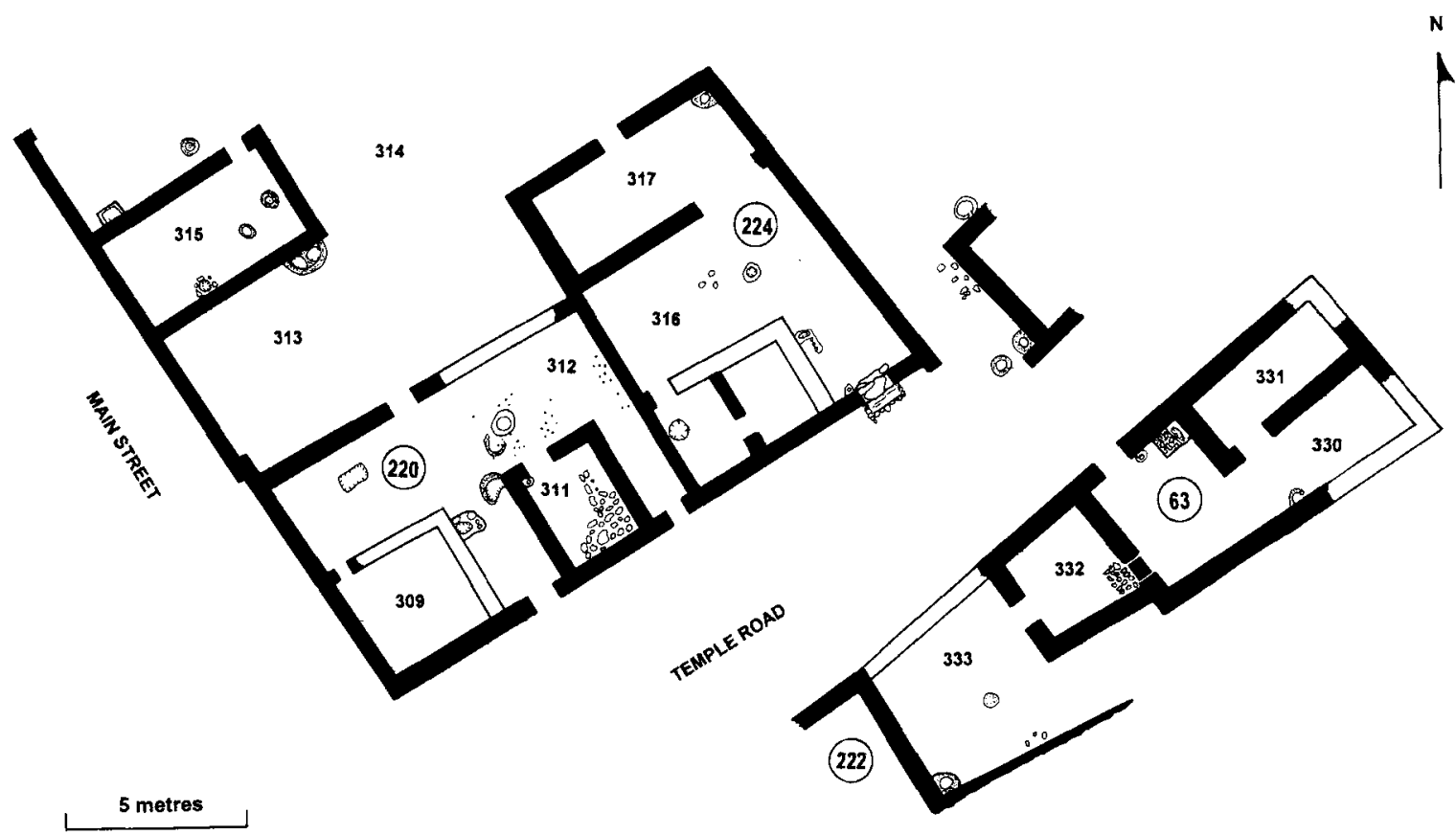

Fig. 6.

Schematic plan of Houses 63, 220, 224.

may have been a partition wall separating the two, perhaps constructed of date-palm fronds.

House 220 was demolished at a later stage and it was perhaps at this point that it suffered some robbing of its walls. Houses 221 and 223 were built over House 220 at a fairly late stage in the history of the settlement, and appear to be contemporary with the latest phase of the temple. The excavation of these fragmentary houses was reported previously (4).

Located in the sand overlying lenses of occupation in Area 314 were the articulated skeletons of five sheep, including one lamb. Unfortunately, it could not be established whether these sheep were contemporary with the Early Dilmun occupation or had been cut from a higher level, although given the absence of later occupation on the site, the former seems most likely. We do not know why they were there but as they were articulated, it was certainly not for food.

Excavation to the north of Area 314 did not reveal any buildings, but deposits of windblown sand interspersed with occasional occupation horizons of burnt sand, shell and pot were found. It seems certain that these represent the edge of the settlement here, and that the build-up of deposits was caused mainly by the deposition of windblown sand accumulating against the northernmost structures of the settlement.

\section{HOUSE 224}

Attached to the northeast side of House 220 was a relatively large house. It was entered from the north side of Temple Road where a flight of three steps led down into the outer L-shaped room.

A narrow stone partition wall, preserved only one course high, subdivided the inner 


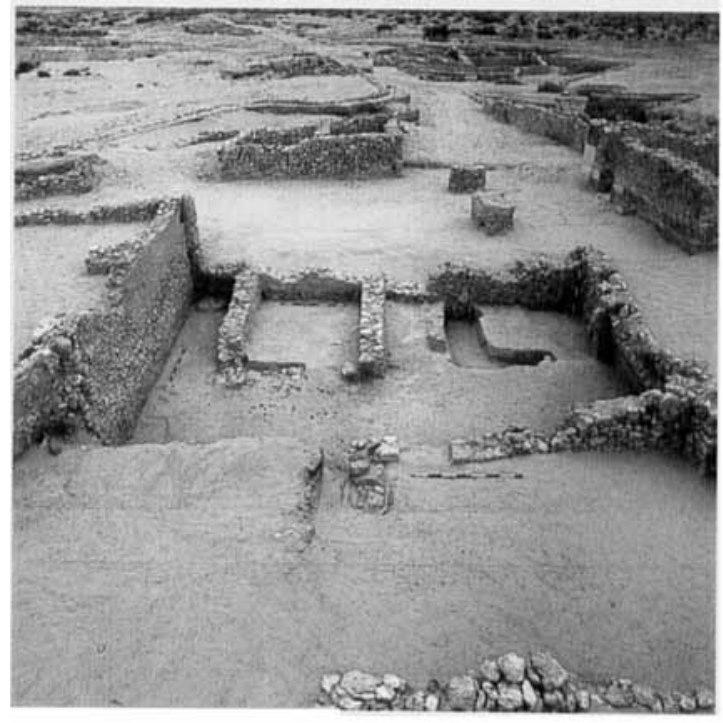

Fig. 7.

House 220 from the north. The groups of stake holes are visible in the floor.

room into two small areas. At the back, was a second yard with a doorway providing access to the north. Inside the house to the left of the main door was a small plastered basin and fragmentary stone bench and in the northeast corner of the house lay a well-preserved tannur with a pottery lining (Fig. 8).

The house had undergone major rebuilding and a $50 \mathrm{~cm}$-deep layer of sand packing separated the floors of the early and late phases. In the early phase, still under investigation, the inner room of the building was located at the north end of the house which had only two rooms at this period. The house was notable for the quality and quantity of finds from the later floors (Figs 9-11). These included five steatite seals and one of clay, a clay token, twenty-seven sealing fragments, eleven clay beads and copper tools including a chisel, an arrowhead, fish-hooks and an awl with a bone handle. The clay token is particularly interesting. A second similar example was found in House 53 and the

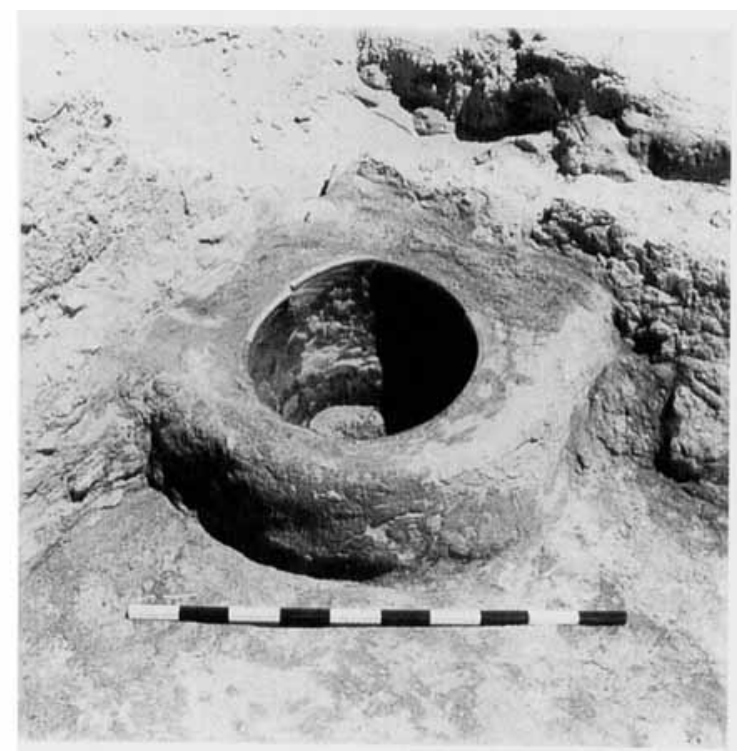

Fig. 8.

House 224, tannur in northeastern corner.

design is also similar to a bi-facial token from the Barbar Temple (5).

Between House 224 and the next building to the northeast was an outdoor area with the remains of two more tannurs and a series of tripod hearths. The surface associated with this kitchen area ran over the top of the collapsed northeast wall of House 224, demonstrating that the house had fallen into disuse prior to the construction of the installations.

\section{The south side of temple road (Shahina Farid)} HOUSE 63

The southeast edge of this house had been damaged by a bulldozer but enough remained to reconstruct the plan. In its first phase the building was a standard threeroomed house: an outer L-shaped area entered from the south side of Temple Road, a rectangular courtyard off to the southwest side and an inner room in the northwest corner. In Area 330, east of the 


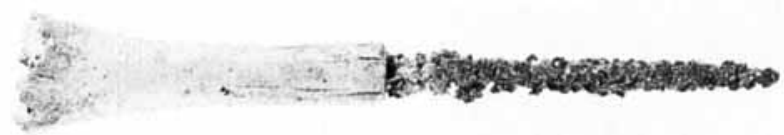

Fig. 9.

Copper awl in bone handle. 5506.03. House 224, Area 316 . Overall tool length: $16 \mathrm{~cm}$. At hafting point: width 1.2 $\mathrm{cm}$, thickness $1.3 \mathrm{~cm}$.

entrance, was a square stone bench and plastered basin and, against the southern wall, a hearth and tripod installation moulded from ash and plaster. These were in a very poor state of preservation due to the collapse of the wall which they had originally abutted.

Subsequently, House 63 was reduced to two rooms. The doorway between Areas 330 and 332 was blocked off and the latter

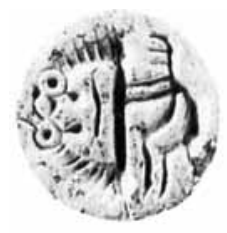

Fig.10.

Miniature seal. 5510.02. House 224, Area 316. Light creamy steatite, glazed. Design: seated monkey facing left, holding a stick or staff with one ruffed neck and head of an animal protruding from each end. Diameter $1.0 \mathrm{~cm}$, height $0.87 \mathrm{~cm}$.

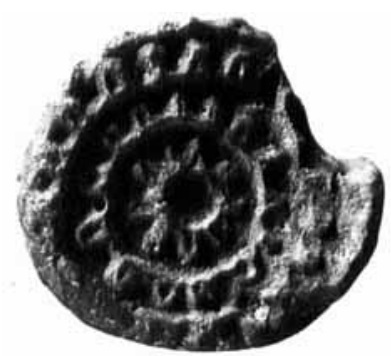

Fig. 11.

Baked clay token. 5500.27. House 224. Large nick taken out of one edge. Triple concentric circles motif with small loops on outer side of each circle. The other side is worn smooth and concave. Diameter 1.85-2.1 $\mathrm{cm}$, height $0.7 \mathrm{~cm}$. area became part of a new two-roomed house which included Area 333. This building is as yet incompletely excavated and therefore further comments will be reserved for our next report.

\section{THE WELL}

Prior to the expedition's arrival in 1995 an old spoil heap on the eastern edge of the mound was removed by a bulldozer. This resulted in a large crater being dug into the side of the mound destroying the upper levels. By chance, this turned out to have a largely beneficial effect: the damage was mostly confined to sand and eroded deposits, the removal of which brought to light the top of a stone structure which turned out to be a well (Fig. 12).

The well was approximately $2.5 \mathrm{~m}$ in diameter and had a stone lining to a depth of $2.15 \mathrm{~m}$. At that depth it hit a shelf of bedrock and the stone lining continued on the south side for a further $1.51 \mathrm{~m}$ resulting in a total extant depth on that side of $3.66 \mathrm{~m}$. The stone lining was neatly constructed with a smooth face and a gradual incline towards the base. A series of stones protruding from this lining provided footholds for access to the bottom. The top of the well had a small stone ledge which may have been to accommodate a lid or cover. A shallow stone channel ran from the well towards the southeast, continuing further on as a shallow cut in the surrounding deposits.

The well had been dug through what appeared to be an agricultural layer rich in heavily-eroded fragments of pottery and 


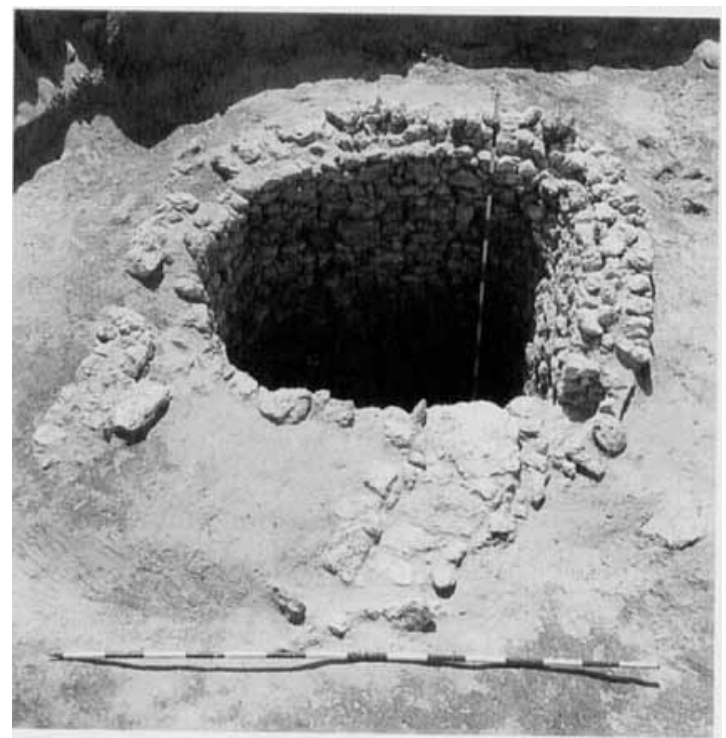

Fig. 12.

The well belonging to an early phase of the settlement.

shell, and associated with it were some fragments of wall to the north, at the bottom of the slope of the mound. These associated buildings have only been partly investigated to date.

The well provides valuable information on the aquifer level in Bahrain in the Early Dilmun period, a matter of some debate. The water level in the well could not have been less than $3.41 \mathrm{~m}$ above sea level, the absolute height at the bottom of the well, and not more than $7.01 \mathrm{~m}$ above sea level, the level of the base of the channel in the side of the well. This might suggest that the underlying aquifer has been depleted far less than previously thought. Larsen, for example, takes $12 \mathrm{~m}$ as the representative elevation for water issuing from the springs in this period (6).

\section{The east side of main street: houses $60-$ 62 (Alex Wasse)}

On the east side of Main Street it was decided to investigate the area between House
222 and House 55 to the southeast. The general plan of the houses in this area is now known, although only House 60 has so far been excavated to its top floor level (Fig. 13).

Starting from the junction with Temple Road, House 222 is separated from House 60 by an alleyway on the south side. There is then a block of two houses (Houses 60 and 61) and then another alley dividing this block from House 62 . House 62 is shown to be the end house in a block of five. Houses 60 and 61 share the same plan. Both are unusual in that they have two inner rooms, each linked by a doorway to the outer Lshaped area. This arrangement is not repeated exactly elsewhere on site, although both Houses 50 and 100 had much smaller inner rooms with a low partition wall. But in both these cases, it was unclear if we were dealing with an actual subdivision of the room or some sort of substructure.

House 60 is entered from Main Street, and immediately inside the house on the left-hand side was a plastered basin with attached bench. In the northeast corner there was an area of stone paving. The house also had a door at the back which led out into an open area.

Outside the rear door to the left was a tannur and two very large plastered tanks (Fig. 14). The eastern half of the second tank had eroded off the edge of the mound, suggesting that the tanks, and indeed all of House 60 in its present form, were constructed at a relatively late date. This was confirmed by an examination of the internal walls of the house which showed them bottoming out at a much higher level than those of the surrounding houses and streets.

\section{West side of main street: house 53 (Jennifer Kiely)}

House 53 is one of a row of substantial domestic buildings along the southwest side of Main Street (Fig. 15). The house was 


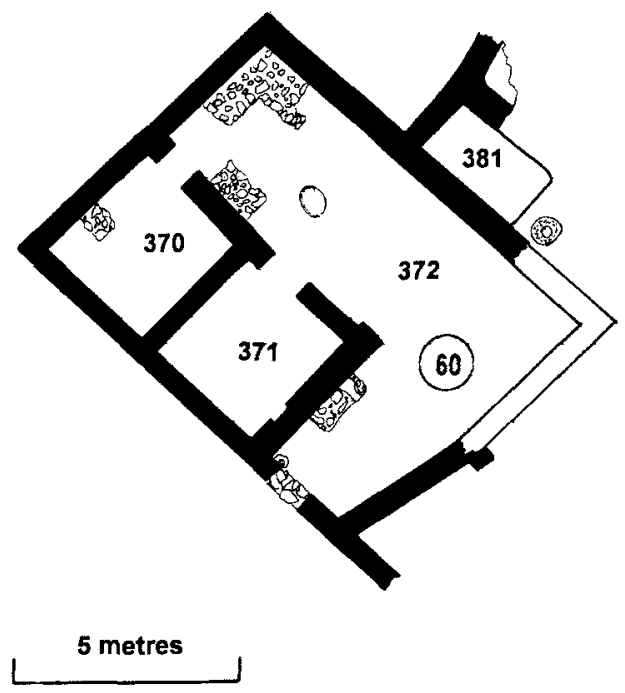

Fig. 13.

Schematic plan of House 60.

entered from the main street via a small porch which afforded protection to the doorway from the north wind. There are two examples of similar porches, at the front of Houses 56 and 101. House 53 deviates slightly from the standard plan at this point, in that the inner room (Area 51) was in the middle of one long side of the courtyard, rather than in a corner, so the open area took the form, not of an L, but of an E without its centre. Access to the room was, as usual, in the side which faces away from the main entrance, and the open area immediately in front of it may have been partitioned off in some way, as the southwest wall of the room projects beyond the corner to form a wide doorway from the main part of the courtyard.

At the back of the courtyard are two doorways. The first, in the southwest wall, led through to an open area (Area 58), in the manner of the 'standard' plan. The open area is, however, much larger than usual. The second doorway in the southeast wall of Area 52 gives onto a completely separate unit, based on an L-shaped

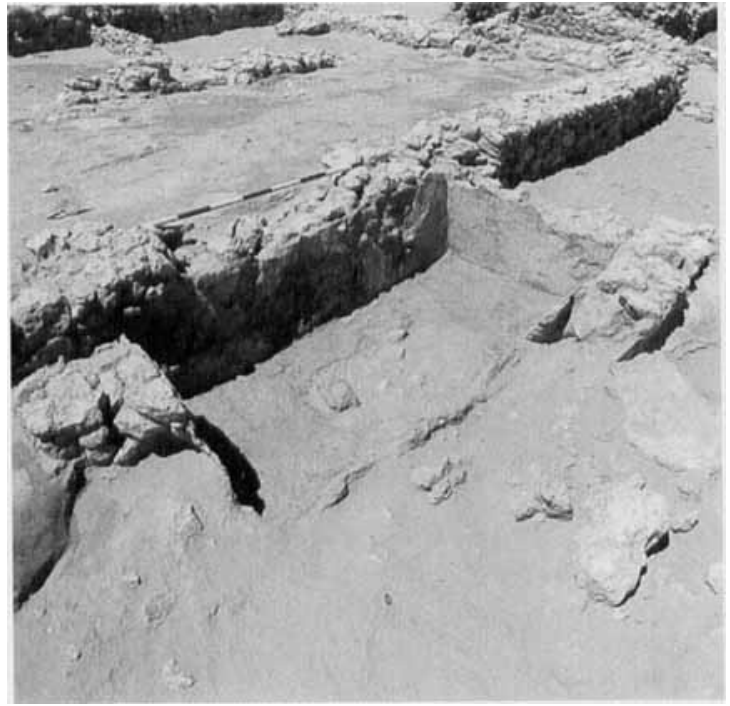

Fig. 14.

House 60, Area 381.

courtyard (Area 61) and its inner room (Area 62). Unfortunately it is not known whether this unit could also be entered from the street, as the northeast edge of the building is lost at this critical point.

Inner room 62 was much larger than its counterpart 51, and the position of the internal buttresses suggests it may have been subdivided (as was the inner room of House 50, at the northwest end of this block of houses). Again, there were two doorways at the back of the courtyard. This time, the one in the southeast wall led into a small and unusual room, Area 64 .

The third part of House 53 contains a courtyard, Area 63, and a range of small rooms, Areas 84-87, ranged along its southeast side (Fig. 16). The open area can be entered from courtyard 61, and perhaps the whole unit should just be seen as a more elaborate form of the usual open area at the back of the standard house.

The house may originally have been two separate dwellings, one comprising Areas 51 and 52, and one Areas 61 and 62, which were combined only late on in the life of 


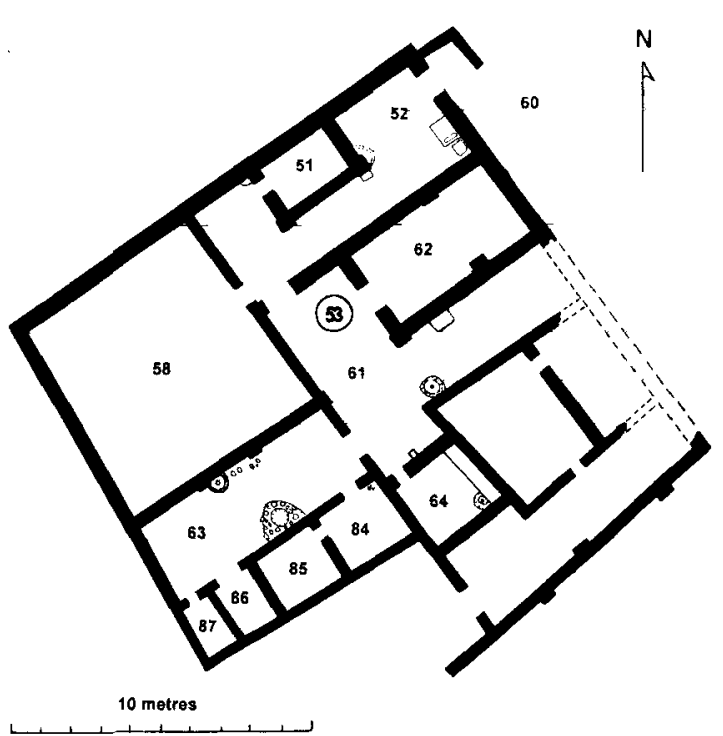

Fig. 15.

Schematic plan of House 53.

the buildings. Nevertheless, in its latest phase House 53 formed an impressive eleven-roomed dwelling, far larger than any building found elsewhere in the settlement.

\section{South alley: houses 206 and 207 (Shahina Farid)}

Excavation was extended along both sides of the alleyway running along the south side of the temple (Fig. 17). House 206 is a late construction slotted into what was an open area at the back of the temple. As it had to be erected in the space between the existing buildings, the plan was skewed, but nevertheless it is one of a typical tworoomed house, except that the outer room had none of the usual kitchen installations. House 206 fell into disuse before the temple, and this is illustrated by the fact that the buttresses against the southwest wall of the temple were constructed on top of a sand deposit which overlaid the latest surface within the house.

The excavation of the neighbouring house, House 207, was carried out in $1 \times 1$

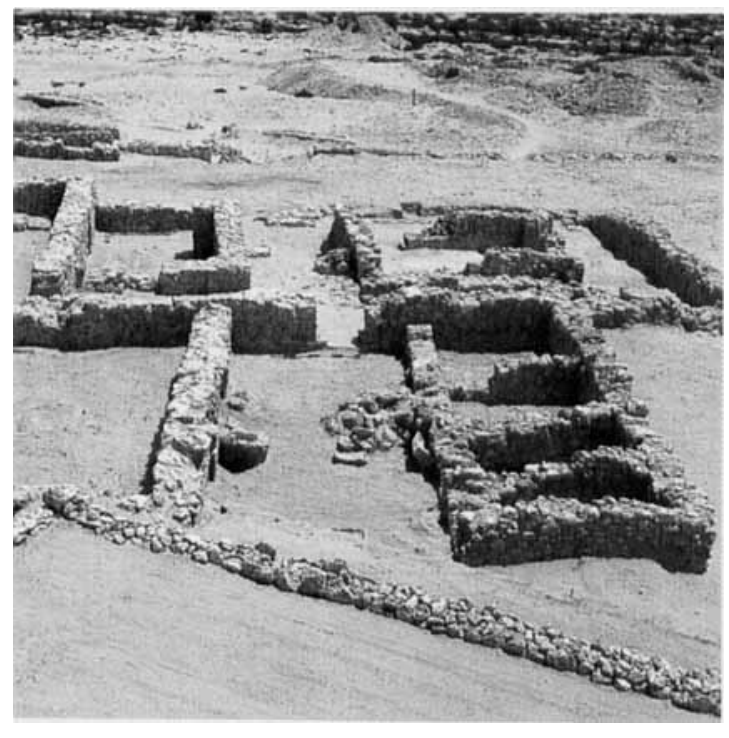

Fig. 16.

House 53 , seen from the western edge.

metre-squares as part of the soil micromorphology programme so that the sequence of occupation and collapse was recorded in greater detail than usual.

Entering the house from the alley, there were to the left a plastered basin with bench and a tannur (Fig. 18). Against the north wall were a horseshoe-shaped hearth and a tripod installation, while in the far corner of the house was a platform of flat stones and a small plastered bench. The floor was fairly even, showing more wear in the passage between the doorways. A stone threshold divided the inner and outer rooms. A large quantity of stone tools were found scattered about in the middle of Area 272, and some stone paving in the southwest corner.

The sequence of collapse of the house was clear. Deposits of windblown sand carried through the doorways accumulated on the floors of the abandoned house. In both rooms, over the sand, was a thick layer of compact mortar interpreted as collapsed roofing material. If micromorphology confirms this suggestion, then it is clear evi- 


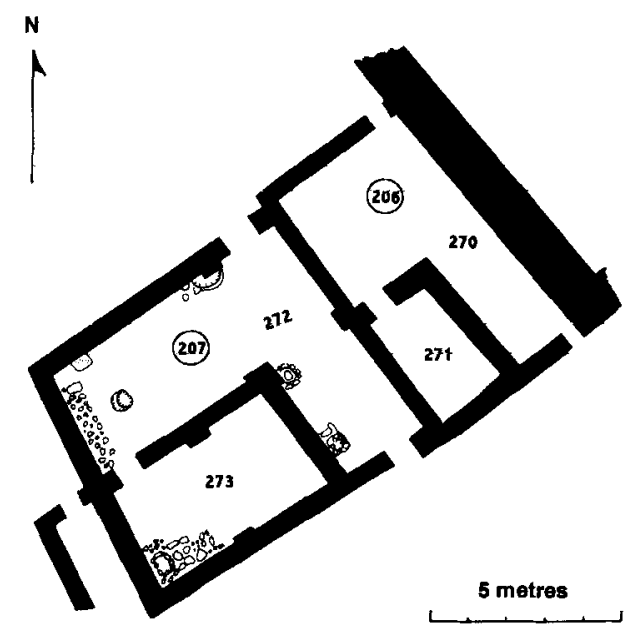

Fig. 17.

Schematic plan of Houses 206 and 207.

dence that, at least in this house, both the inner and outer rooms of the house were roofed.

\section{Limits of the settlement}

There has long been a question mark about the exact size and limits of the settlement at Saar (7). In particular, the presence of pottery sherds off the ridge on which the settlement stands, both to the north and to the east, suggested that there might have been further buildings under the plain in these directions. During the 1995 season a programme of remote sensing was carried out both on the site and around the periphery. Resistivity and magnetometry were used, and this was followed up by selective excavation to test what the instruments were telling us. There were two objectives: to establish the limits of the settlement and to see if such techniques could detect the plan of unexcavated buildings within the settlement.

Starting from the northern excavated edge of the town (immediately north and west of House 208), an area of $15,000 \mathrm{~m}^{2}$ was systematically covered by resistivity.

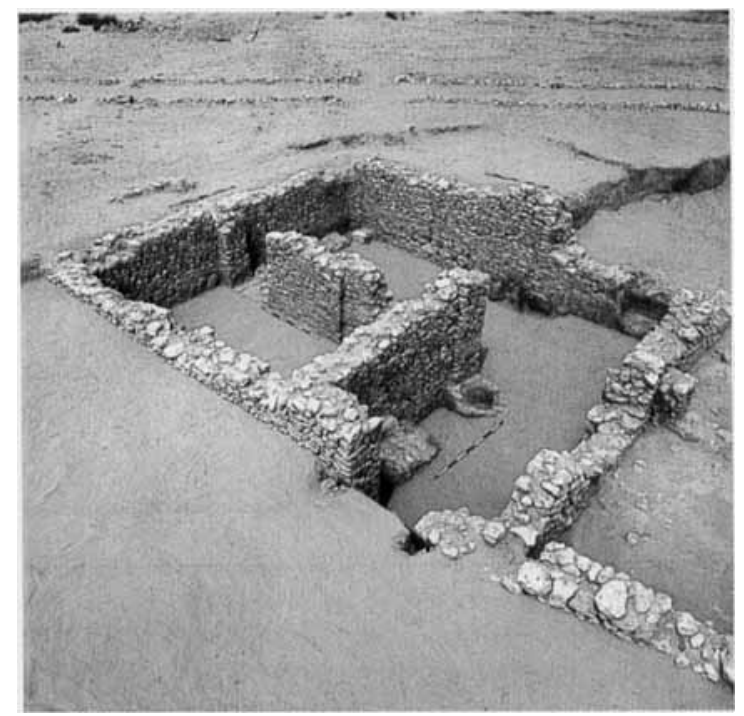

Fig. 18.

House 207 from the south.

Some patterns did emerge from the resulting plots, but excavation at selected points showed that these reflected different soil conditions and did not indicate the presence of buildings. The soils in the plain had been reworked as a result of recent agricultural activity. An evaluation trench only $30 \mathrm{~m}$ northwest of House 208 revealed no archaeological deposits. Further round to the east, our excavations suggest that the northern slope beyond House 220 is also devoid of structures.

Coupled with other observations we have made about the limits to the west and south, we can now state that the settlement at Saar probably did not exceed $22,500 \mathrm{~m}^{2}$ (2.25 ha). It is strung out along the side of the limestone ridge for a distance of approximately $250 \mathrm{~m}$, whereas its maximum width across the ridge is only $100 \mathrm{~m}$, and in some places considerably less. The site is thus smaller and far more compact than we had estimated previously.

Within the known area of the settlement, the resistivity survey succeeded in detecting some individual buildings west of 
the temple, and this was useful as a presence/absence indicator. In this area conditions were particularly favourable, with the walls of the houses lying immediately below the surface and the rooms in-filled with sand and minimal stone rubble. How ever, the results were not precise enough to provide a plan of any of the buildings.

\section{Acknowledgements}

We are grateful for the support of HE Mohammed AlMuttawa, Minister of Cabinet Affairs and Information, Shaikha Nayla Al-Khalifa, Director of the National Museum and Mr. Khalid Sindi, Curator of Antiquities. Our major supporters for the 1994 and 1995 seasons at Saar were Al Ahli Commercial Bank, Aluminium Bahrain (Alba), Bahrain Petroleum Company (Bapco), The British Academy, Ministry of Cabinet Affairs and Information, and Phillip Morris.

Further financial support was provided by the British School of Archaeology in Iraq, Caltex, Jashanmals, McDonald Institute for Archaeological Research, National Bank of Bahrain, Standard Chartered Bank and from all the companies and institutions listed below. We wish to extend our thanks to them all.

ABN Amro, Adel Fakhro Enterprises, African \& Eastern (Bahrain), Airmech, AJM Kooheji \& Sons, Al Ahlia Insurance Co., Al Hilal Group, Al Jazira Cold Store Co., Al Zamil Group, American Women's Association, A.T. \& T., Awal Plastics, Bahrain Airport Services, Bahrain Financing Company, Bahrain Flour Mills, Bahrain Jewellery Centre, Bahrain Insurance Co., Bahrain International Bank, Bahrain Maritime \& Mercantile International, Bahrain Technical \& Trading Co., Banagas, Bank of Bahrain \& Kuwait, Banque Nationale de Paris, Banz, Basrec, Batelco, British Bank of the Middle East, Budget Rent-A-Car, Business International, The British Council, Cathay Pacific, Chemical Bank, Clifford Chance, Credit Suisse, Diplomat Hotel, Ernst \& Young, Flemings, Fortune Promoseven, G.P. Zachariades, Gulf Daily News, Gulf Business Machines, Gulf Colour Laboratories, Gulf Petrochemical Industries Corporation, Hasan Mansouri, Inchcape Middle East, Intercol, Kimberly-Clark Regional Services (Bahrain), Kodak (Near East) Incorporated, KPMG Fakhro, Linacre Associates (Overseas) Ltd, Merrill Lynch, Mohammed Jalal \& Sons, National Imports \& Exports Co., National Insurance Co., Oriental Press, Swiss Bank Corporation, Unitag, United Gulf Bank, United Gulf Industries Corporation, United Insurance Co., YBA Kanoo, Yateem Brothers.

\section{References}

1. The following staff participated in both seasons: Shahina Farid, Martin Hicks, Alison Hicks (archaeologists), Dan Barrett (surveyor), Kirsty Norman (conservator), Hilary Towns (administrator), Harriet Crawford (glyptic specialist), Marcus Woodburn (assistant director \& photographer), Robert Killick and Jane Moon (directors). Additional staff were, for 1994: Marlies Heinz (pottery technologist), Brian Irving (fish specialist), Jennifer Kiely (archaeologist), Wendy Murphy (finds registrar), Emily Glover (shell specialist), Duncan Woodburn (illustrator) and Chantelle Waddingham (volunteer); and for 1995: Robyn Stocks (finds registrar), Sarah Blakeney, Ben Bellefroid, Alex Wasse (archaeologists), Dominique de Moulins (archaeobotanist), Lewis Somers (geophysicist), Idunn Kvalo, Jonathan Gillan and Nabil Al Shaikh (volunteers). Our colleagues from the Ministry of Information were Mustafa Ibrahim, Khalil Faraj and Abdulla Hassan.

2. To simplify descriptions of the location of the houses in the central area of the site, we have given names to some of the streets and alleyways. The main artery running through the town from NW to SE is Main Street, the road running down away from the temple to the NE is Temple Road and the alleyways either side of the temple have been labelled North and South Alley.

3. Moon J et al. London-Bahrain Archaeological Expedition excavations at Saar: 1993 season. $A A E$ 1995: 6: 144-147.

4. Moon et al. London-Bahrain Archaeological Expedition: 148 .

5. Lombard P \& Kervran M, eds. Bahrain National Museum Archaeological Collections, Vol 1: a selection of pre-Islamic antiquities from excavations 1954-1975, 154. Bahrain: Ministry of Information, 1989.

6. Larsen CE. Life and Land Use on the Bahrain Islands: the Geoarcheology of an Ancient Society. Chicago: University of Chicago, 1983: 137.

7. Killick RG et al. London-Bahrain Archaeological Expedition: 1990 excavations at Saar. AAE 2: 1991: 110.

Address:

Robert Killick

Institute of Archaeology

31-34 Gordon Square

London WC1M OPY 